\title{
Peace and Conflict: Engineering Responsibilities and Opportunities
}

Robert J. Muscat, Global Peace Services USA

\begin{abstract}
In many conflicts, the consequences of engineering projects are among the problems at issue, and engineers are unavoidably parties to the problems. Engineers need to raise their awareness of the potential effects of their projects, especially in situations of serious social and political contention, and to explore alternative designs or engineering solutions, and methods of implementation, that may ameliorate rather than exacerbate tensions. Engineers will also need to dialogue effectively with the many stakeholders affected if these projects are to be politically viable and achieve their technical purposes. The paper draws on several case studies of engineering projects in conflict situations, especially in developing countries. The article offers a check list of factors to take into account when designing and locating power, irrigation, mining, transport, and other types of engineering projects, in areas of conflict or potential conflict. The focus of the paper is primarily, but not entirely, on social conflict.
\end{abstract}

\section{Introduction}

Conflicts among communities, peoples, and nations can arise from many causes, and often escalate to violence and warfare. In many cases, engineering programs and projects are among the problems at issue. Engineering professionals may unavoidably be parties to the problem. They may also be well placed to prevent or ameliorate the problem in the first place, or contribute to a peaceful resolution. The social responsibilities facing engineers has become a subject of its own, explored in books and engineering ethics journals. Apart from their role in the development and manufacture of armaments, the relationships between engineering and conflict, especially in developing countries, have been less well examined.

Many engineering projects in the U.S. are sources of political conflict, e.g. disputes over the location of wind farms; the technology for, and unintended consequences of, extracting natural gas from shale formations; environmental effects of mining projects; location and risks of offshore oil drilling. Although such disputes can reach fever pitch, they have not ended in violent conflict. In developing countries, by contrast, groups that viewed their vital interests at stake in engineering decisions have sometimes resorted to violence to resolve disputes not settled through negotiation or orderly political process. In some cases, engineering projects have deepened intergroup animosities that may have arisen initially for other reasons - religious, cultural, economic or political.

There have also been positive-sum outcomes, where projects have been designed and decided through processes deliberately aimed at avoiding exacerbation of underlying animosities. Even more proactive are engineering investments designed to create common economic and/or communal interests among groups in societies marked by socio-economic fault lines. 
In the most extreme cases (for example, in Iraq and Afghanistan), engineering projects have been implemented in the midst of active warfare, often designed to influence the allegiance of the expected beneficiaries.

\section{The Roles of Engineers}

Engineers are found at advisory, decision-making, or design levels in the processes leading up to project realization in conflict situations. Engineers also play important roles in the management and operation of projects once they come on line. While senior engineers will have greater responsibility for decisions and options chosen, professionals at all levels are in position to consider the social and conflict consequences of projects they work on, and to put their views on the table. The feasibility of projects, technical and economic considerations aside, often depends on how stakeholders view the potential consequences. The individual engineer may be a political office-holder, a civil servant, an executive or employee in a private contracting firm, a private consultant, an academic in an engineering faculty, or on the staff of an international development organization. Many engineering fields may be involved in conflict-laden contexts - civil, hydraulic, electrical, transport, mining, petroleum, agricultural, etc. Those responsible for the technical core need to develop: a) skills of coordination, negotiation, and communication with stakeholders; b) the ability to take account of environmental, social, and other impact studies; and c) the ability to work in multidisciplinary teams.

The World Bank's experience with hydroelectric and irrigation projects in developing countries shows how projects have had to be developed beyond their technically-defined boundaries to take account of connections with other disciplines, and of possible conflict effects. For years the Bank avoided hydroelectric projects after incurring severe criticism for ignoring bad outcomes for displaced and indigenous people. The Bank resumed hydro projects in the 1990s after adopting safeguard requirements on compensation, and attention to potential conflicts.

\section{Examples: Exacerbation vs. Prevention}

International frictions over natural resource development claims can grow into outright conflict. Examples of areas with worrisome overlapping claims include islands in the South China Sea (with oil-potential), claimed by Vietnam, Taiwan, and China; northern and southern Sudan (oil production and pipelines); division of water resources among Lebanon, Israel, and West Bank Palestine; and hydro and irrigation schemes along the Mekong River affecting downstream countries. Internal conflicts in developing countries - over mineral, land, water and other development projects - have arisen in (among others) Peru, Colombia, India, Papua New Guinea, Mexico, Ecuador, Ghana, and Bangladesh.

Proper engineering solutions can prevent violent outcomes. Soon after partition separated Pakistan from India in 1947, it became clear that failure to create a system for control and distribution of the Indus River basin waters acceptable to both countries could result in warfare. The World Bank took the lead in designing, negotiating, and financing a multi-dam irrigation solution. Unfortunately, although the program was adopted and implemented, resolving the Indus dispute, India and Pakistan have had other disputes that have led to recurrent armed conflict. 
An unequivocally successful example is the Gal Oya irrigation project in Sri Lanka, built in 1948-1952. The upper arms of the canals watered areas occupied by ethnic Sinhalese, the country's dominant ethnicity, who drew most of the water before it could reach the lower stretches that fed minority Tamil areas. To create a win-win situation, farmer groups were set up to oversee cooperative water distribution, ensuring that the downstream Tamils received enough flow for cultivation. Despite efforts of the Tamil Tigers, the insurgent side in the Sri Lankan civil war (1983-2009), to persuade Tamil farmers to cease cooperating with their Sinhalese neighbors, the groups held fast. Relations between the Gal Oya ethnic communities remained, and still are, peaceful and mutually beneficial.

By contrast, another Sri Lankan irrigation scheme became a major missed opportunity where major engineering works exacerbated a deep socio-political conflict. The massive Mahaweli project, begun in 1970, the biggest engineering works in the island's history, was first designed with a channel that would have delivered water to the largely Tamil region of northern Sri Lanka. In 1977 the Sri Lankan authorities redesigned the project to exclude the northern channel. The decision was defended on ostensibly technical engineering grounds, but was seen by the Tamils as demonstrating Sinhalese discrimination and hegemony. The government also discriminated against Tamils in the settlement plan for land that would be newly opened by the project. Retaining the original designs of this major project might have helped avert the subsequent political deterioration that spiraled into warfare.

A rural development project in Rwanda that started in 1974 is another example of a missed opportunity that turned out to exacerbate tensions. In this case, the benefits (including structures, roads, and land access) were largely captured by local Hutus, excluding Tutsis. The final result was judged by one African scholar to be an increase in inequality between regions and social and ethnic groups.

In two examples from Thailand, irrigation projects were constructed (in the 1950s-1970s) to win population loyalty in a region that was poor and had been traditionally neglected by the central government. Some were built despite awareness that the projects' economic justifications were dubious. Others were built even though the sponsoring and designing engineering authorities knew that due to poor soil conditions the projects could not meet minimum engineering standards. In these decisions, the expected social and political benefits were seen as justifying the sub-optimal engineering.

Projects to improve transportation can help develop poor regions. New or improved roads can lower the costs of getting agricultural produce to markets. These projects can also have downsides where they open up areas already inhabited by people previously marginal in terms of economic or political power. New low-cost access can draw developers of large-scale agriculture, cattle-ranching, or resource extraction, who may expropriate the land of the previously isolated inhabitants. This has been a significant problem in northern Brazil.

\section{Examples of Questions in Project Design}

To be alert to the relevance of projects to potential conflict, engineers (and others involved in planning and implementation) should take account of factors such as: 
1) Is the project located near borders between rival groups?

2) Will the location and design of irrigation channels impinge on divisions between different ethnic (or religious, etc.) groups?

3) In the case of international waterways, consider the World Bank's safeguards.

4) The World Bank cautions should similarly be applied to projects in internationally contested areas, and in border-spanning resource development (e.g. natural gas, petroleum, water).

5) Are there external "diseconomies" (e.g. pollution causing health or economic damage) that should be taken into account in the project design?

6) Is a project affecting areas inhabited by indigenous people? How will this affect design, cost, negotiation, and implementation?

7) Will environmental degradation caused by a mining project be justifiable, minimized?

8) Will there be fair compensation payments/projects for people negatively affected?

9) Will road location raise issues of equity and benefits between favored and omitted communities?

In general, engineers should seek opportunities for project designs that create motivation for peaceful coexistence or cooperation, or at least do no harm. Engineering education could further this objective by enriching curricula with peace education components, relevant multidisciplinary materials, and specific engineering case studies and issues, as suggested above.

\section{Questions for Discussion}

1. To what extent are engineering schools' curricula addressing these issues, including preparing students for multi-disciplinary professional collaboration? Do the curricula need enrichment in these respects, and if so, how should this be done?

2. Do the perspectives described in the paper need to be widely understood and considered with the engineering professions, and if so, how could this be accomplished? What institutions/organizations within the engineering community are best placed for leadership roles in such an effort?

3. In the next few decades, global climate change is likely to be a major new source of conflict, and a major subject for engineering responses (and engineering employment). To what extent are engineering schools preparing the next generation of engineers for the central role they will be playing in this area? Does this preparation include appreciation of the social and political complexities involved, including the stresses and conflicts of interest that are likely to be intense?

4. How should engineering research be enriched to integrate these socio-political aspects with the purely technical engineering research subjects? 


\section{Selected Bibliography}

Banfield, J. \&Tripathi, S. (2006). Conflict-sensitive business practices: Engineering contractors and their clients. London, UK: International Alert. Retrieved from http://www.international alert.org/resources/publications.

Fox, James W. (2011) Evaluation of the Implementation of the Paris Declaration by the U.S. Government: Millennium Challenge Corporation Case Study. Washington, DC. Retrieved from http://www.oecd.org/development/evaluation/dcdndep/47780793.

Haney, M. \& Plummer, J. (2008). Taking a holistic approach to planning and developing hydropower: Lessons from two river basin case studies in India. Washington, DC: World Bank. Retrieved from https://openknowledge.worldbank.org/handle/10986/10597.

Muscat, Robert J. (2002) Investing in Peace: How development aid can prevent or promote conflict. Armonk, NY: M.E.Sharpe.

Survival for Tribal Peoples (n.d.). The Yanomami. Retrieved from http://www.survivalinternational.org/tribes/Yanomami.

Uphoff, Norman (1998) Learning from Gal Oya. Ithaca, NY: Cornell University Press.

World Bank (2012). Operational Manual. Washington DC: World Bank 